\title{
VEGF $936 C>T$ is predictive of threshold retinopathy of prematurity in Japanese infants with a 30-week gestational age or less
}

This article was published in the following Dove Press journal:

Research and Reports in Neonatology

2 March 201I

Number of times this article has been viewed

\author{
Mariko Yagi' \\ Motohiro Yamamori ${ }^{4}$ \\ Ichiro Morioka ${ }^{2}$ \\ Naoki Yokoyama ${ }^{2}$ \\ Shigeru Honda ${ }^{3}$ \\ Akira $\mathrm{Negi}^{3}$ \\ Tsutomu Nakamura' \\ Noboru Okamura ${ }^{4}$ \\ Katsuhiko Okumura' \\ Toshiyuki Sakaeda ${ }^{5}$ \\ Masafumi Matsuo ${ }^{2}$ \\ 'Department of Clinical Evaluation \\ of Pharmacotherapy, ${ }^{2}$ Department of \\ Pediatrics, ${ }^{3}$ Department of Surgery, \\ Division of Ophthalmology, Kobe \\ University Graduate School of \\ Medicine, Kobe, Japan; ${ }^{4}$ Department \\ of Clinical Pharmacy, School of \\ Pharmaceutical Sciences, Mukogawa \\ Women's University, Nishinomiya, \\ Japan; ${ }^{5}$ Center for Integrative \\ Education of Pharmacy Frontier, \\ Graduate School of Pharmaceutical \\ Sciences, Kyoto University, \\ Kyoto, Japan
}

Correspondence: Mariko Yagi Department of Clinical Evaluation of Pharmacotherapy, Kobe University Graduate School of Medicine, 7-5-I, Kusunokicho, Chuo, Kobe 650-0017, Japan

Tel +8I 783826090

Fax +8I 783826099

Email myagi@med.kobe-u.ac.jp

\begin{abstract}
Vascular endothelial growth factor (VEGF) contributes to the development of retinopathy of prematurity (ROP). We investigated the association of ROP with VEGF genetic polymorphisms and its clinical parameters in Japanese people. Sixty-seven infants with a gestational age of 30 weeks or less were enrolled and classified into the threshold ROP group (infants with Stage 3 ROP in zone I or II, five continuous or eight total clock hours of the retina and the presence of plus disease, $\mathrm{n}=30)$ and the nonthreshold ROP group $(\mathrm{n}=37)$. The $V E G F$ genotypes of $-1498 \mathrm{~T}>\mathrm{C},-1154 \mathrm{G}>\mathrm{A},-634 \mathrm{C}>\mathrm{G},-7 \mathrm{C}>\mathrm{T}, 936 \mathrm{C}>\mathrm{T}$, and $1612 \mathrm{G}>\mathrm{A}$ were determined. $V E G F 936 \mathrm{C}>\mathrm{T}$ polymorphism and 11 clinical parameters were significantly different between the two ROP groups by univariate analysis. A logistic regression analysis with adjustments for gestational age and birth weight showed that the heterozygous or homozygous carrier state of the $\mathrm{T}$ alleles of $V E G F 936 \mathrm{C}>\mathrm{T}$ polymorphism (odds ratio 5.12; 95\% confidence interval: $1.25-20.92 ; P=0.023$ ) and duration of oxygen administration (odds ratio $1.05 ; 95 \%$ confidence interval: $1.00-1.10 ; P=0.042$ ) were independent risk factors of threshold ROP. $V E G F 936 \mathrm{C}>\mathrm{T}$ polymorphism may predict threshold ROP in Japanese infants with a gestational age of 30 weeks or less.
\end{abstract}

Keywords: retinopathy of prematurity, vascular endothelial growth factor, gene polymorphism, premature infant

\section{Introduction}

In spite of improvements in perinatal care, retinopathy of prematurity (ROP) remains a major complication among premature infants. ROP can cause retinal detachment resulting in visual loss or permanent blindness. ROP is a multifactorial disease, and several studies have identified risk factors such as short gestational age, low birth weight, excessive oxygen supplementation, blood transfusion, and recombinant erythropoietin exposure. ${ }^{1-8}$ However, there is no reliable method for predicting whether ROP will regress spontaneously or progress in spite of adequate treatment.

$\mathrm{ROP}$ is characterized by incomplete and abnormal neovascularization of the retina in premature infants. It is known that vascular endothelial growth factor (VEGF), a major mediator of vascular permeability and angiogenesis, is necessary for vascular growth in the neonatal retina. ${ }^{9,10}$ Increased VEGF synthesis and high levels of VEGF have been observed in the hypoxic retina of an animal model, ${ }^{11,12}$ whereas other experiments have shown that inhibition of VEGF prevented retinal ischemia-associated neovascularization. ${ }^{13,14}$ Furthermore, the importance of VEGF in the development of ROP has been supported by data from several clinical studies. ${ }^{15-18}$ 
The VEGF gene (gene symbol: VEGFA, gene ID: 7422) is located on chromosome 6q21.3, and consists of eight exons and seven introns. ${ }^{19}$ Various polymorphisms of the $V E G F$ gene have been identified that influence the expression levels of VEGF protein. ${ }^{20-24}$ It has been recently reported that genetic polymorphism in the $V E G F$ gene promoter may influence the progression of ROP. ${ }^{25-28}$ However, there are no data about the correlation between $V E G F$ gene polymorphisms and risk of ROP in the Japanese population.

In the present study, we investigated the association of ROP with $V E G F$ genetic polymorphisms and clinical (maternal, perinatal, neonatal) parameters in the Japanese population by using univariate and multivariate analyses.

\section{Methods and materials}

\section{Patients}

Sixty-seven infants with an estimated 30 weeks' gestational age or less were enrolled in this study. They included 52 single infants, six pairs of twins, and one pair of triplets. All infants were treated at the neonatal intensive care unit in Kobe University Hospital. The study was approved by the ethics committee of the Kobe University Graduate School of Medicine, and written informed consent was obtained from the patients' parents.

The first ophthalmic examination was performed at 3-4 weeks of age, and was followed up until 40 weeks postconceptual age. ROP degree was classified according to the International Committee for Classification of Retinopathy of Prematurity. ${ }^{29}$ Threshold disease of ROP is considered to be present when Stage 3 ROP is present in either zone I or zone II, with at least five continuous or eight total clock hours of disease, and the presence of plus disease..$^{30}$ For the purpose of this study, the 67 infants were divided into two groups, ie, a threshold ROP group and a nonthreshold ROP group. The threshold ROP group consisted of 30 infants and the nonthreshold ROP group included 37 infants.

Maternal and perinatal variables documented included maternal age, gravidity, parity, maternal exposure to antenatal steroids, maternal smoking, delivery route, pregnancyinduced hypertension, premature rupture of membranes, threatened premature labor, nonreassuring fetal state, pathological chorioamnionitis, pathological funisitis, and placental infarction.

The variables recorded at birth included gestational age (based on the date of the last menstrual period), birth weight, gender, intrauterine growth restriction, multiple births, and APGAR scores at 1 minute and 5 minutes. Variables recorded after birth included the number of surfactant administrations, administration of catecholamines, glucoseinsulin infusion, duration of mechanical ventilation, duration of oxygen treatment, neonatal jaundice requiring phototherapy, septicemia (positive blood culture), hypoglycemia, patent ductus arteriosus, intraventricular hemorrhage, chronic lung disease, apnea, dexamethasone exposure, administration of recombinant erythropoietin, transfusion, and exchange transfusion. Chronic lung disease was diagnosed when the infants required oxygen therapy at 36 weeks' corrected postnatal gestational age. ${ }^{31}$ The laboratory findings at birth included the first count of white blood cells, hemoglobin level, creatine kinase level, C-reactive protein, and IgM. A serum C-reactive protein concentration of $>1.0 \mathrm{mg} / \mathrm{dL}$ was defined as significantly elevated. A serum IgM concentration of $>20 \mathrm{mg} / \mathrm{dL}$ at birth was regarded as clinically significant.

\section{VEGF genotyping}

Genomic DNA was extracted from the buccal mucosa or umbilical cord using a DNeasy Tissue Kit (Qiagen, Hilden, Germany), according to the manufacturer's directions. Using the public National Center for Biotechnology Information Single Nucleotide Polymorphism database and available literature, we selected six VEGF candidate polymorphisms, ie, $-1498 \mathrm{~T}>\mathrm{C}(\mathrm{rs} 833061)$ and $-1154 \mathrm{G}>\mathrm{A}(\mathrm{rs} 1570360)$ in the promoter region, $-634 \mathrm{C}>\mathrm{G}$ (rs2010963) and $-7 \mathrm{C}>\mathrm{T}$ (rs25648) in the 5' UTR, and 936C $>$ T (rs3025039) and $1612 \mathrm{G}>\mathrm{A}$ (rs10434) in the 3' UTR. Each polymorphism showed a minor allele frequency of at least 0.10 in the Japanese population, ${ }^{23,32-35}$ and all polymorphisms were investigated in terms of their association with various types of diseases or clinical situations. ${ }^{22,36-39}$ The six VEGF genotypes were evaluated using TaqMan ${ }^{\mathrm{R}}$ minor groove binding probe-based polymerase chain reaction, and confirmed by direct sequencing, as described previously. ${ }^{40}$

\section{Statistical analysis}

Values were expressed as means \pm standard deviations. Statistical analysis was performed using the SPSS statistical package (version 14.0; SPSS Inc., Chicago, IL). The statistical significance of differences between the mean values was calculated for unpaired samples using a Student's $t$-test or Welch's $t$-test, provided that the samples were normally distributed. If this was not the case, a Mann-Whitney $U$ test was applied. In the categorical univariate analysis, the dependent variable was the threshold or nonthreshold ROP 
as defined earlier. Some independent variables were classified into two or three categories. The Fisher's exact test was used to evaluate the relationship between these independent variables and ROP. The significant factors in the univariate analysis were then included in further analyses, including a stepwise logistic regression model, with adjustments for gestational age and birth weight. In all analyses, $P$ values less than 0.05 (two-tailed) were considered to be statistically significant.

\section{Results}

Univariate and multivariate analyses were performed in the 67 patients, some of whom had missing data. The mean gestational age of preterm infants in the threshold ROP group was significantly shorter than that in the nonthreshold ROP group (26.8 \pm 1.8 [range 23.4-29.7] weeks versus $28.7 \pm 1.6$ [range 25.7-30.9]) weeks. The average birth weights of the preterm infants were also significantly different between the threshold and nonthreshold ROP group ( $875 \pm 258$ and $1052 \pm 221 \mathrm{~g}$, respectively). APGAR scores at 1 minute and 5 minutes, duration of artificial ventilation, and duration of oxygen administration significantly affected the development of threshold ROP as well. Pregnancy-induced hypertension, number of surfactant administrations, chronic lung disease, transfusion, and septicemia were significant risk factors of developing threshold ROP by univariate analysis of categorized factors. The risk of threshold ROP was not significantly influenced by other tested factors (Table 1).

The VEGF polymorphisms $-1498 \mathrm{~T}>\mathrm{C},-1154 \mathrm{G}>\mathrm{A}$, $-634 \mathrm{C}>\mathrm{G},-7 \mathrm{C}>\mathrm{T}, 936 \mathrm{C}>\mathrm{T}$, and $1612 \mathrm{G}>\mathrm{A}$ were found at an allele frequency of 45/128, 27/128, 79/128, 21/128, $25 / 128$, and $14 / 128$, respectively. The distribution of the $V E G F$ 936C $>$ T polymorphism showed a significant statistical difference between the threshold ROP and nonthreshold ROP groups. However, there was no difference in distribution of the other polymorphisms for the $V E G F$ gene between the threshold and nonthreshold ROP groups (Table 2).

Amongst the 12 significant risk factors in the univariate analysis, gestational age and birth weight appeared to be important for ROP. To prevent the possible effects of confounding factors, a subsequent multivariate logistic analysis was performed with an adjustment for gestational age and birth weight. In addition, six patients with missing data were excluded from the following multivariate analysis to improve accuracy. The numbers of surfactant administrations and septicemia were excluded from the multivariate analysis because no infants without surfactant administration and all infants with septicemia developed threshold ROP, and the $95 \%$ confidence interval (CI) was wide. The multivariate logistic regression analysis showed that duration of oxygen administration (odds ratio 1.05; $95 \%$ CI: $1.00-1.10 ; P=0.042$ ) and the heterozygous or homozygous carrier state of $\mathrm{T}$ alleles of $V E G F$ 936C $>\mathrm{T}$ polymorphism (odds ratio 5.12; 95\% CI: $1.25-20.92 ; P=0.023$ ) were independent risk factors for the development of threshold ROP (Table 3). These factors allowed the diagnosis of ROP with $80.3 \%$ confidence.

\section{Discussion}

In the present study, we found that $V E G F 936 \mathrm{C}>\mathrm{T}$ polymorphism and duration of oxygen administration were independent risk factors for threshold ROP using a multivariate logistic analysis with adjustment for gestational age and birth weight.

The importance of VEGF in the development of ROP has been reported in several previous studies. Sonmez et al demonstrated that intravitreous levels of VEGF were elevated in Stage 4 ROP. This suggests that VEGF is highly active in Stage 4 ROP, and is more likely to play a key role in the maintenance of neovascularization. ${ }^{18}$ Another study investigated 38 cases of Stage 5 ROP at vitrectomy, and revealed increased VEGF immunoreactivity in the vascularized regions of fibrovascular membranes. ${ }^{17}$ Meanwhile, two studies have reported about the systemic VEGF levels in infants; one described that the plasma VEGF level was similar in both infants with and without $\mathrm{ROP}^{41}$ and the other reported that serum VEGF level in infants with ROP requiring treatment was significantly lower than that in infants without ROP. ${ }^{28}$ From these studies, the correlation between the development of ROP and systemic VEGF level remains unclear. It is probable that pathogenic retinal angiogenesis in ROP is mostly driven by local VEGF synthesis.

Recently, various genetic polymorphisms in the VEGF gene have been identified that influence the levels of VEGF expression. Our results showed that there was a significant difference in distribution of the $936 \mathrm{C}>\mathrm{T}$ genotype in premature Japanese infants with threshold ROP. While this finding is intriguing, our present pilot study was limited by small sample size. A further study with a larger sample size could clarify the VEGF genotype-specific effect on threshold ROP.

The 936C $>$ T polymorphism is located in the 3' UTR of the $V E G F$ gene which is an important regulatory site controlling mRNA stability and translation under certain conditions. ${ }^{42-44}$ 
Table I Univariate analysis of categorized and noncategorized factors associated with threshold ROP

\begin{tabular}{|c|c|c|c|}
\hline Variable $^{a}$ & $\begin{array}{l}\text { Nonthreshold ROP } \\
(n=37)\end{array}$ & $\begin{array}{l}\text { Threshold ROP } \\
(n=30)\end{array}$ & $P$ value $^{a}$ \\
\hline \multicolumn{4}{|l|}{ Maternal and perinatal variables } \\
\hline Maternal age (years) & $32.7 \pm 5.1$ & $31.2 \pm 4.4^{b}$ & 0.211 \\
\hline Gravidity & $2.4 \pm 1.5$ & $2.2 \pm 1.3$ & 0.479 \\
\hline Parity & $0.8 \pm 1.0$ & $0.6 \pm 0.7$ & 0.534 \\
\hline Maternal smoking (no/yes) & $27 / 9^{b}$ & $27 / 2^{b}$ & 0.094 \\
\hline Pregnancy-induced hypertension (no/yes) & $28 / 9$ & $29 / 1$ & 0.019 \\
\hline Threatened premature delivery (no/yes) & $24 / 13$ & $12 / 18$ & 0.052 \\
\hline Premature rupture of membranes (no/yes) & $30 / 7$ & $21 / 9$ & 0.390 \\
\hline Antenatal steroids (no/yes) & $18 / 18^{b}$ & $18 / 12$ & 0.464 \\
\hline Nonreassuring fetal state (no/yes) & $32 / 5$ & $27 / 3$ & 0.722 \\
\hline Pathological funisitis (no/yes) & $30 / 3^{b}$ & $22 / 6^{b}$ & 0.279 \\
\hline Pathological chorioamnionitis (no/yes) & $20 / 13^{b}$ & $15 / 14^{b}$ & 0.609 \\
\hline Placental infarction (no/yes) & $27 / 6^{\mathrm{b}}$ & $24 / 4^{\mathrm{b}}$ & 0.741 \\
\hline \multicolumn{4}{|l|}{ Variables at birth } \\
\hline Gender (male/female) & $21 / 16$ & $15 / 15$ & 0.628 \\
\hline Gestational age (weeks) & $28.7 \pm 1.6$ & $26.8 \pm 1.8$ & $<0.001$ \\
\hline Birth weight (g) & $1052 \pm 221$ & $875 \pm 258$ & 0.004 \\
\hline Intrauterine growth retardation (no/yes) & $22 / 15$ & $22 / 8$ & 0.304 \\
\hline APGAR score at I min & $6.6 \pm 2.0$ & $4.8 \pm 2.3$ & 0.002 \\
\hline $5 \mathrm{~min}$ & $8.1 \pm 1.5$ & $6.9 \pm 2.1$ & 0.004 \\
\hline Delivery route (cesarean/vaginal) & $33 / 4$ & $26 / 4$ & 1.000 \\
\hline Multiple birth (no/yes) & $29 / 8$ & $23 / 7$ & 1.000 \\
\hline \multicolumn{4}{|l|}{ Variables after birth } \\
\hline Number of surfactant administration $(0 / 1 / \geq 2)$ & $7 / 16 / 14$ & $0 / 21 / 9$ & 0.013 \\
\hline Duration of artificial ventilation (days) & $37.2 \pm 22.2^{\mathrm{b}}$ & $59.3 \pm 19.3^{b}$ & $<0.001$ \\
\hline Duration of oxygen administration (days) & $47.6 \pm 20.6$ & $76.9 \pm 26.6$ & $<0.001$ \\
\hline Chronic lung disease (no/yes) & $24 / 13$ & $8 / 22$ & $<0.003$ \\
\hline Dexamethasone exposure (no/yes) & $36 / 1$ & $26 / 3^{b}$ & 0.312 \\
\hline Patent ductus arteriosus (no/yes) & $27 / 10$ & $17 / 13$ & 0.200 \\
\hline Catecholamine administration (no/yes) & $3 / 34$ & $0 / 30$ & 0.247 \\
\hline Glucose-insulin infusion (no/yes) & $33 / 4$ & $21 / 9$ & 0.065 \\
\hline Transfusion (no/yes) & $31 / 5^{b}$ & $14 / 16$ & 0.001 \\
\hline Exchange blood transfusion (no/yes) & $36 / 0^{\mathrm{b}}$ & $27 / 3$ & 0.089 \\
\hline Erythropoietin administration (no/yes) & $3 / 34$ & $0 / 30$ & 0.247 \\
\hline Neonatal jaundice requiring phototherapy (no/yes) & $1 / 36$ & $0 / 30$ & 1.000 \\
\hline Hypoglycemia (no/yes) & $30 / 7$ & $28 / 2$ & 0.172 \\
\hline Apnea (no/yes) & $8 / 29$ & $13 / 17$ & 0.069 \\
\hline Intraventricular hemorrhage (no/yes) & $34 / 3$ & $27 / 3$ & 1.000 \\
\hline Septicemia, positive blood culture (no/yes) & $37 / 0$ & $24 / 6$ & 0.006 \\
\hline \multicolumn{4}{|l|}{ Laboratory findings at birth } \\
\hline White blood cells $(\times 100 / \mu \mathrm{L})$ & $73.8 \pm 58.3$ & $92.0 \pm 66.5$ & 0.273 \\
\hline Hemoglobin (g/dL) & $15.9 \pm 2.2$ & $14.9 \pm 2.1$ & 0.079 \\
\hline C-reactive protein (no/yes) & $36 / 1$ & $29 / 0^{b}$ & 1.000 \\
\hline Creatine kinase (IU/L) & $321 \pm 144$ & $30 \mathrm{I} \pm 208^{b}$ & 0.321 \\
\hline IgM (no/yes) & $35 / 2$ & $28 / I^{b}$ & 1.000 \\
\hline
\end{tabular}

Notes: Values for noncategorized factors were expressed as means \pm standard deviations. ${ }^{\text {a } V a r i a b l e s ~ w i t h ~} P<0.05$ in the univariate analysis are indicated in italics; bThese patients had missing data.

Abbreviation: ROP, retinopathy of prematurity.

To date, it has been reported that the $936 \mathrm{C}>\mathrm{T}$ polymorphism affects plasma VEGF level, and adult carriers of a $936 \mathrm{~T}$ allele have significantly reduced levels of plasma VEGF. ${ }^{22,45,46}$ However, no data are available on the genetic effects on VEGF level in immature eyes. Meanwhile, the computationally predicted potential binding sites for miR210, miR-517a, miR-517b, and miR-517c included the 936C $>$ T polymorphic site in the VEGF mRNA 3' UTR. ${ }^{47}$ Although the roles of these microRNAs remain obscure, it has been reported that miR-210 is upregulated in various cell 
Table 2 Genotype distribution for the VEGF polymorphism in threshold and nonthreshold ROP

\begin{tabular}{|c|c|c|c|}
\hline Variable $^{a}$ & $\begin{array}{l}\text { Nonthreshold } \\
\text { ROP } \\
(n=37)\end{array}$ & $\begin{array}{l}\text { Threshold } \\
\text { ROP } \\
(n=30)\end{array}$ & $P$ value ${ }^{a}$ \\
\hline \multicolumn{4}{|l|}{ VEGF genotype } \\
\hline$-1498 \mathrm{~T}>\mathrm{C}(\mathrm{TT} / \mathrm{TC} / \mathrm{CC})$ & $19 / 10 / 5^{b}$ & $10 / 15 / 5$ & 0.172 \\
\hline$-1154 G>A(G G / G A / A A)$ & $24 / 9 / I^{b}$ & $16 / 12 / 2$ & 0.412 \\
\hline$-634 \mathrm{C}>\mathrm{G}(\mathrm{CC} / \mathrm{CG} / \mathrm{GG})$ & $6 / 16 / 12^{b}$ & $3 / 15 / 12$ & 0.699 \\
\hline$-7 \mathrm{C}>\mathrm{T}(\mathrm{CC} / \mathrm{CT} / \mathrm{TT})$ & $52 / 9 / 0^{\mathrm{b}}$ & $19 / 10 / 1$ & 0.492 \\
\hline $936 \mathrm{C}>\mathrm{T}(\mathrm{CC} / \mathrm{CT} / \mathrm{TT})$ & $27 / 7 / 0^{\mathrm{b}}$ & $\mid 4 / 14 / 2$ & 0.012 \\
\hline $1612 \mathrm{G}>\mathrm{A}(\mathrm{GG} / \mathrm{GA} / \mathrm{AA})$ & $26 / 8 / 0^{b}$ & $24 / 6 / 0$ & 0.771 \\
\hline
\end{tabular}

Notes: ${ }^{\text {V }}$ ariables with $P<0.05$ in the univariate analysis are indicated in italics; 'These patients had missing data.

Abbreviations: ROP, retinopathy of prematurity; VEGF, vascular endothelial growth factor.

lines under hypoxic conditions. ${ }^{47-50}$ Fasanaro et al have also reported that miR-210 upregulation in normoxic conditions increased tubulogenesis and migration in the endothelial cell line, whereas the blockade of miR-210 under hypoxia led to inhibition of tubulogenesis and migration. ${ }^{48,49}$ Given the regulatory protein and certain microRNAs that potentially promote mRNA degradation or delay translation bind to the 936C $>$ T polymorphic site in the VEGF mRNA 3'-UTR, recognition of the specific mRNA sequence and secondary structure by these regulatory factors may be disrupted by the polymorphism. It was speculated that VEGF $936 \mathrm{~T}$ allele was responsible for hindering and delaying mRNA degradation or translational silencing, and subsequently a persistent ocular VEGF level, leading to abnormal neovascularization in immature eyes.

In contrast with our results, Cooke et al described that there was no association between the allele state of $V E G F$ 936C $>$ T and risk of ROP. However, we cannot directly compare our results with those of Cooke et al because our study is dissimilar with respect to the patient gestational age, birth weight, and ethnic background. ${ }^{25}$ In addition, the association of the $V E G F-1498 \mathrm{~T}>\mathrm{C}$ and $-634 \mathrm{G}>\mathrm{C}$

Table 3 Logistic regression analysis of the risk factors for threshold ROPa

\begin{tabular}{llll}
\hline Variable $^{\mathrm{b}}$ & Odds ratio & $\mathbf{9 5 \%} \mathbf{C l}$ & $\boldsymbol{P}_{\text {value }}^{\mathrm{b}}$ \\
\hline $\begin{array}{l}\text { Duration of oxygen administration } \\
\text { VEGF } 936 \mathrm{C}>\mathrm{T}\end{array}$ & $\mathrm{I} .05$ & $1.00-1.10$ & 0.042 \\
CC & $\mathrm{I}$ & & \\
CT, TT & 5.12 & $1.25-20.92$ & 0.023 \\
\hline
\end{tabular}

Notes: ${ }^{a} \mathrm{~A}$ logistic regression analysis with adjustment for gestational age and birth weight was performed in 61 preterm infants; ${ }^{b}$ Variables with $P<0.05$ in the univariate analysis are indicated in italics.

Abbreviations: $\mathrm{Cl}$, confidence interval; ROP, retinopathy of prematurity; VEGF, vascular endothelial growth factor. polymorphisms with the risk of threshold ROP has also been examined, resulting in inconsistent results across groups. ${ }^{25,26,28,51}$ In the present study, there was no association between VEGF $-1498 \mathrm{~T}>\mathrm{C}$ or $-634 \mathrm{G}>\mathrm{C}$ polymorphism and risk of threshold ROP in premature Japanese infants. There is a possibility that the $936 \mathrm{C}>\mathrm{T}$ polymorphism is related to $-1498 \mathrm{~T}>\mathrm{C}$ and/or $-634 \mathrm{G}>\mathrm{C}$ polymorphisms, and a further haplotype analysis might provide a rational explanation for these discrepancies.

Some previous studies have suggested septicemia as a risk factor. ${ }^{52-54}$ Septicemia may injure developing blood vessels in the retina, induce the release of cytokines or growth factors, and result in threshold ROP. In the present study, all infants with septicemia developed threshold ROP. Septicemia was suggested as a risk factor of ROP. However, the CI was wide, and we did not make adjustments for the multivariate analysis.

In conclusion, $V E G F 936 \mathrm{C}>\mathrm{T}$ polymorphism and duration of oxygen administration are significant independent risk factors for threshold ROP, even after gestational age and birth weight are controlled for. Our data suggest that infants with the $936 \mathrm{~T}$ allele need to be monitored closely for development of threshold ROP so that they may receive effective photocoagulation therapy $V E G F 936 \mathrm{C}>\mathrm{T}$ polymorphism is predictive of the development of threshold ROP in Japanese infants of 30 weeks' gestational age or less, but further investigations with larger populations are required to confirm the associations between $V E G F$ polymorphism and ROP.

\section{Acknowledgment}

This study was supported in part by a Grant-in-Aid for Scientific Research from the Ministry of Education, Culture, Sports, Science, and Technology, Japan.

\section{Disclosure}

The authors report no conflicts of interest in this work.

\section{References}

1. Sacks LM, Schaffer DB, Anday EK, Peckham GJ, DelivoriaPapadopoulos M. Retrolental fibroplasia and blood transfusion in very low-birth-weight infants. Pediatrics. 1981;68(6):770-774.

2. Flynn JT. Acute proliferative retrolental fibroplasia: Multivariate risk analysis. Trans Am Ophthalmol Soc. 1983;81:549-591.

3. Bossi E, Koerner F, Flury B, Zulauf M. Retinopathy of prematurity: A risk factor analysis with univariate and multivariate statistics. Helv Paediatr Acta. 1984;39(4):307-317.

4. Prendiville A, Schulenburg SW. Clinical factors associated with retinopathy of prematurity. Arch Dis Child. 1988;63(5):522-527.

5. Cooke RW, Clark D, Hickey-Dwyer M, Weindling AM. The apparent role of blood transfusions in the development of retinopathy of prematurity. Eur J Pediatr. 1993;152(10):833-836. 
6. Karna P, Muttineni J, Angell L, Karmaus W. Retinopathy of prematurity and risk factors: A prospective cohort study. BMC Pediatr. 2005; 5(1): 18 .

7. Akkoyun I, Oto S, Yilmaz G, et al. Risk factors in the development of mild and severe retinopathy of prematurity. J AAPOS. 2006;10(5): 449-453.

8. Brown MS, Barón AE, France EK, Hamman RF. Association between higher cumulative doses of recombinant erythropoietin and risk for retinopathy of prematurity. JAAPOS. 2006;10(2):143-149.

9. Alon T, Hemo I, Itin A, Pe'er J, Stone J, Keshet E. Vascular endothelial growth factor acts as a survival factor for newly formed retinal vessels and has implications for retinopathy of prematurity. Nat Med. 1995;1(10):1024-1028.

10. Pierce EA, Avery RL, Foley ED, Aiello LP, Smith LE. Vascular endothelial growth factor/vascular permeability factor expression in a mouse model of retinal neovascularization. Proc Natl Acad Sci U S A. 1995;92(3):905-909.

11. Donahue ML, Phelps DL, Watkins RH, LoMonaco MB, Horowitz S. Retinal vascular endothelial growth factor (VEGF) mRNA expression is altered in relation to neovascularization in oxygen induced retinopathy. Curr Eye Res. 1996;15(2):175-184.

12. Stone J, Chan-Ling T, Pe'er J, Itin A, Gnessin H, Keshet E. Roles of vascular endothelial growth factor and astrocyte degeneration in the genesis of retinopathy of prematurity. Invest Ophthalmol Vis Sci. 1996;37(2):290-299.

13. Aiello LP, Pierce EA, Foley ED, et al. Suppression of retinal neovascularization in vivo by inhibition of vascular endothelial growth factor (VEGF) using soluble VEGF-receptor chimeric proteins. Proc Natl Acad Sci U S A. 1995;92(23):10457-10461.

14. Adamis AP, Shima DT, Tolentino MJ, et al. Inhibition of vascular endothelial growth factor prevents retinal ischemia-associated iris neovascularization in a nonhuman primate. Arch Ophthalmol. 1996;114(1):66-71.

15. Young TL, Anthony DC, Pierce E, Foley E, Smith LE. Histopathology and vascular endothelial growth factor in untreated and diode lasertreated retinopathy of prematurity. J AAPOS. 1997;1(2):105-110.

16. Lashkari K, Hirose T, Yazdany J, McMeel JW, Kazlauskas A, Rahimi N. Vascular endothelial growth factor and hepatocyte growth factor levels are differentially elevated in patients with advanced retinopathy of prematurity. Am J Pathol. 2000;156(4):1337-1344.

17. Umeda N, Ozaki H, Hayashi H, Miyajima-Uchida H, Oshima K. Colocalization of Tie2, angiopoietin 2 and vascular endothelial growth factor in fibrovascular membrane from patients with retinopathy of prematurity. Ophthalmic Res. 2003;35(4):217-223.

18. Sonmez K, Drenser KA, Capone A Jr, Trese MT. Vitreous levels of stromal cell-derived factor 1 and vascular endothelial growth factor in patients with retinopathy of prematurity. Ophthalmology. 2008;115(6):1065-1070.

19. Tischer E, Mitchell R, Hartman T, et al. The human gene for vascular endothelial growth factor. Multiple protein forms are encoded through alternative exon splicing. J Biol Chem. 1991;266(18):11947-11954.

20. Brogan IJ, Khan N, Isaac K, Hutchinson JA, Pravica V, Hutchinson IV. Novel polymorphisms in the promoter and 5' UTR regions of the human vascular endothelial growth factor gene. Hum Immunol. 1999;60(12):1245-1249.

21. Watson CJ, Webb NJ, Bottomley MJ, Brenchley PE. Identification of polymorphisms within the vascular endothelial growth factor (VEGF) gene: Correlation with variation in VEGF protein production. Cytokine. 2000;12(8):1232-1235.

22. Renner W, Kotschan S, Hoffmann C, Obermayer-Pietsch B, Pilger E. A common $936 \mathrm{C} / \mathrm{T}$ mutation in the gene for vascular endothelial growth factor is associated with vascular endothelial growth factor plasma levels. J Vasc Res. 2000;37(6):443-448.

23. Awata T, Inoue $\mathrm{K}$, Kurihara S, et al. A common polymorphism in the 5 '-untranslated region of the VEGF gene is associated with diabetic retinopathy in type 2 diabetes. Diabetes. 2002;51(5):1635-1639.
24. Shahbazi M, Fryer AA, Pravica V, et al. Vascular endothelial growth factor gene polymorphisms are associated with acute renal allograft rejection. J Am Soc Nephrol. 2002;13(1):260-264.

25. Cooke RW, Drury JA, Mountford R, Clark D. Genetic polymorphisms and retinopathy of prematurity. Invest Ophthalmol Vis Sci. 2004;45(6):1712-1715.

26. Vannay A, Dunai G, Bányász I, et al. Association of genetic polymorphisms of vascular endothelial growth factor and risk for proliferative retinopathy of prematurity. Pediatr Res. 2005;57(3):396-398.

27. Bányász I, Bokodi G, Vannay A, et al. Genetic polymorphisms of vascular endothelial growth factor and angiopoietin 2 in retinopathy of prematurity. Curr Eye Res. 2006;31(7-8):685-690.

28. Kwinta P, Bik-Multanowski M, Mitkowska Z, Tomasik T, Pietrzyk JJ. The clinical role of vascular endothelial growth factor (VEGF) system in the pathogenesis of retinopathy of prematurity. Graefes Arch Clin Exp Ophthalmol. 2008;246(10):1467-1475.

29. Committee for the Classification of Retinopathy of Prematurity. An international classification of retinopathy of prematurity. Arch Ophthalmol. 1984;102(8):1130-1134.

30. Phelps DL. Retinopathy of prematurity: History, classification, and pathophysiology. NeoReviews. 2001;2(7):e153-e166.

31. Shennan AT, Bik-Multanowski M, Ohlsson A, Lennox K, Hoskins EM. Abnormal pulmonary outcomes in premature infants: Prediction from oxygen requirement in the neonatal period. Pediatrics. 1988;82(4):527-532.

32. Abe A, Sato K, Habuchi T, et al. Single nucleotide polymorphisms in the 3' untranslated region of vascular endothelial growth factor gene in Japanese population with or without renal cell carcinoma. Tohoku J Exp Med. 2002;198(3):181-190.

33. Kariyazono H, Ohno T, Khajoee V, et al. Association of vascular endothelial growth factor (VEGF) and VEGF receptor gene polymorphisms with coronary artery lesions of Kawasaki disease. Pediatr Res. 2004;56(6):953-959.

34. Morohashi K, Takada T, Omori K, Suzuki E, Gejyo F. Vascular endothelial growth factor gene polymorphisms in Japanese patients with sarcoidosis. Chest. 2003;123(5):1520-1526.

35. Ikuhashi Y, Yosihda S, Kennedy S, et al. Vascular endothelial growth factor $+936 \mathrm{C} / \mathrm{T}$ polymorphism is associated with an increased risk of endometriosis in a Japanese population. Acta Obstet Gynecol Scand. 2007;86(11):1352-1358.

36. Howell WM, Bateman AC, Turner SJ, Collins A, Theaker JM. Influence of vascular endothelial growth factor single nucleotide polymorphisms on tumour development in cutaneous malignant melanoma. Genes Immun. 2002;3(4):229-232.

37. Papazoglou D, Galazios G, Koukourakis MI, Kontomanolis EN, Maltezos E. Association of $-634 \mathrm{G} / \mathrm{C}$ and $936 \mathrm{C} / \mathrm{T}$ polymorphisms of the vascular endothelial growth factor with spontaneous preterm delivery. Acta Obstet Gynecol Scand. 2004;83(5):461-465.

38. Shim JY, Jun JK, Jung BK, et al. Vascular endothelial growth factor gene $+936 \mathrm{C} / \mathrm{T}$ polymorphism is associated with preeclampsia in Korean women. Am J Obstet Gynecol. 2007;197(3):e271-e274.

39. Kong SY, Park JW, Lee JA, et al. Association between vascular endothelial growth factor gene polymorphisms and survival in hepatocellular carcinoma patients. Hepatology. 2007;46(2):446-455.

40. Yamamori M, Sakaeda T, Nakamura T, et al. Association of VEGF genotype with mRNA level in colorectal adenocarcinomas. Biochem Biophys Res Commun. 2004;325(1):144-150.

41. Pieh C, Agostini H, Buschbeck C, et al. VEGF-A, VEGFR-1, VEGFR-2 and Tie2 levels in plasma of premature infants: Relationship to retinopathy of prematurity. Br J Ophthalmol. 2008;92(5):698-693.

42. Ciais D, Cherradi N, Bailly S, et al. Destabilization of vascular endothelial growth factor mRNA by the zinc-finger protein TIS11b. Oncogene. 2004;23(53):8673-8680.

43. Pagès G, Pouysségur J. Transcriptional regulation of the vascular endothelial growth factor gene - a concert of activating factors. Cardiovasc Res. 2005;65(3):564-573. 
44. Ray PS, Jia J, Yao P, Majumder M, Hatzoglou M, Fox PL. A stressresponsive RNA switch regulates VEGFA expression. Nature. 2009;457(7231):915-919.

45. Krippl P, Langsenlehner U, Renner W, et al. A common 936 C/T gene polymorphism of vascular endothelial growth factor is associated with decreased breast cancer risk. Int J Cancer. 2003;106(4):468-471.

46. Zhai R, Gong MN, Zhou W, et al. Genotypes and haplotypes of the VEGF gene are associated with higher mortality and lower VEGF plasma levels in patients with ARDS. Thorax. 2007;62(8):718-722.

47. Hua Z, Lv Q, Ye W, et al. MiRNA-directed regulation of VEGF and other angiogenic factors under hypoxia. PLoS One. 2006;1(1):e116.

48. Kulshreshtha R, Ferracin M, Wojcik SE, et al. A microRNA signature of hypoxia. Mol Cell Biol. 2007;27(5):1859-1867.

49. Fasanaro P, D’Alessandra Y, Di Stefano V, et al. MicroRNA210 modulates endothelial cell response to hypoxia and inhibits the receptor tyrosine kinase ligand Ephrin-A3. J Biol Chem. 2008;283(23):15878-15883.
50. Huang X, Le QT, Giaccia AJ. MiR-210 - micromanager of the hypoxia pathway. Trends Mol Med. 2010;16(5):230-237.

51. Shastry BS, Qu X. Lack of association of the VEGF gene promoter $(-634 \mathrm{G}->\mathrm{C}$ and $-460 \mathrm{C}->\mathrm{T})$ polymorphism and the risk of advanced retinopathy of prematurity. Graefes Arch Clin Exp Ophthalmol. 2007;245(5):741-743.

52. Haroon Parupia MF, Dhanireddy R. Association of postnatal dexamethasone use and fungal sepsis in the development of severe retinopathy of prematurity and progression to laser therapy in extremely low-birthweight infants. J Perinatol. 2001;21(4):242-247.

53. Gupta VP, Dhaliwal U, Sharma R, Gupta P, Rohatgi J. Retinopathy of prematurity - risk factors. Indian J Pediatr. 2004;71(10):887-892.

54. Liu PM, Fang PC, Huang CB, et al. Risk factors of retinopathy of prematurity in premature infants weighing less than 1600 g. Am J Perinatol. 2005;22(2):115-120.

\section{Publish your work in this journal}

Research and Reports in Neonatology is an international, peer-reviewed, open access journal publishing original research, reports, editorials, reviews and commentaries on neonatal health. The manuscript management system is completely online and includes a very quick and fair peer-review system. Visit http://www.dovepress.com/testimonials.php to read real quotes from published authors. 